\title{
Opinion
}

\section{Long Non-Coding RNAs “Key Orchestrators” in Cancers}

\author{
Venkata Narasimha Kadali*¹, Sheji Chandran ${ }^{1}$, Smitha Murthy ${ }^{2}$
}

${ }^{1}$ Research Assosciate, Department of Molecular Biology, Credora Life Sciences, Bangalore, India.

${ }^{1}$ Scientist, Department of Molecular Biology, Credora Life Sciences, Bangalore, India.

${ }^{2}$ Director, Avrio Genomics \& Credora Life Sciences, Bangalore, India.

\section{Correspondence}

Venkata Narasimha Kadali

Research Assosciate, Credora Life Sciences, Bengaluru, Karnataka, India-560043.

Email: vnsimhakadali@gmail.com

Phone: +919989340062 


\begin{abstract}
Long Non-Coding RNAs (lncRNAs) attaining impeccable attention in recent times owing to their expanded roles in the cell. They essentially perform a decisive task to regulate the genes in conjunction with developmental processes. In cancers the lncRNAs involves in the cell proliferation, migration and invasion made them as "key Orchestrators". In this precise opinion, we brief the role of IncRNAs in cancer with a note on their proteincoding potential.
\end{abstract}

\title{
Keywords
}

Long Non-Coding RNA, Cancer, Cell proliferation

Research studies revealed the human genome encodes only $2 \%$ of protein-coding genes and certainly, the rest of the genome is transcribed into tiny pieces of nonprotein-coding RNAs acknowledged as noncoding RNA (ncRNAs) [1]. Noncoding RNA categorized into small noncoding RNA, for instance, micro RNA and other class being are long non-coding RNAs (lncRNAs). IncRNAs grouped into sense lncRNAs, antisense lncRNAs, intronic lncRNAs, long intergenic lncRNAs, promoter-associated lncRNAs, bi-directional lncRNAs, natural antisense transcriptions and enhancer lncRNAs [2].

Long noncoding RNAs typically 200 nucleotides $-100 \mathrm{~kb}$ transcripts that lack open reading frame belongs to a team of noncoding RNAs (ncRNAs) $[3,4]$. Like usual mRNA often codes for a protein, the lncRNAs are also spliced, capped as well as polyadenylated [5]. LncRNAs possess the ability to bind to the DNA, RNA in addition to proteins to execute their effects on gene expression utilizing diversified mechanisms [6].

lncRNAs regulate gene expression at transcriptional, posttranscriptional and epigenetic levels [7]. At the epigenetic level, they regulate through RNA interference, DNA methylation or demethylation, chromatin remodeling and histone modifications [8-14]. 
Detection of Structurally complex long non-coding RNA (lncRNA) helped to comprehend the physiology of the cell in addition to disease pathogenesis [6]. Deregulated expression of lncRNA plays a vital role in diseases [15]. Altered expression of LncRNAs in cancers as well as in other diseases were reported[16,17].

LncRNAs may serve as potential markers for therapeutic intervention in various diseases. Research studies clearly remarked that lncRNAs incredibly heterogeneous and exhibit significant functional versatility due to their conformations they assume in the course of their developmental processes and positively assisting all of them to interact with other molecules [18].

Chung-Chau Hon et al.. [19] in their study stated that long noncoding RNAs are unquestionably functional orchestrators in multiple diseases. Extremely diversified lncRNA interact with various proteins which play a decisive role in the pathogenesis of various disease conditions [20].

lncRNA also experiences mutations as like protein-coding genes in such cases they become more powerful in cancers by contributing to the formation of tumours and metastasis [21]. The lncRNA inactivates major tumour suppressor genes and lead to carcinogenesis [22] LncRNAs could display characters like, promoting cancers or suppress cancers [21]. Recently Oskar Marín-Béjar et al. [23] reported a lncRNA titled LINC-PINT (long intergenic non-protein coding RNA, p53 induced transcript) that typically behaves as a tumour suppressor, lowering the invasive character of cancer cells. Additionally, they pointed out that this is achieved merely by an interaction between a highly conserved sequence element in LINC-PINT with polycomb repressor complex 2 (PRC2).

Recently discovered lncRNAs role and mechanism of action in various cancers summarized in Table 1 
Table 1: The lncRNAs role and mechanism of action in various cancers

\begin{tabular}{|c|c|c|c|c|}
\hline IncRNA & $\begin{array}{l}\text { Type of } \\
\text { Cancer }\end{array}$ & Role in Cancer & Mechanism of Action & Reference \\
\hline $\begin{array}{l}\text { AGAP2- } \\
\text { AS1 }\end{array}$ & $\begin{array}{l}\text { Small Lung } \\
\text { Cancer }\end{array}$ & $\begin{array}{l}\text { Cell proliferation, } \\
\text { migration, and invasion }\end{array}$ & $\begin{array}{l}\text { AGAP2-AS1 attaches to the } \\
\text { enhancer of zeste homolog } 2 \text { and } \\
\text { lysine (K)-specific demethylase 1A } \\
\text { and forms a complex which binds to } \\
\text { the promoter region of tumor- } \\
\text { suppressorLATS2 and KLF2 to } \\
\text { repress their transcription. }\end{array}$ & [17] \\
\hline LINC00152 & $\begin{array}{l}\text { Gallbladder } \\
\text { cancer }\end{array}$ & $\begin{array}{c}\text { Cell migration, } \\
\text { invasion and epithelial- } \\
\text { mesenchymal transition (EMT) }\end{array}$ & $\begin{array}{l}\text { LINC00152 binds to miR-138 and } \\
\text { repress the HIF-1 } \alpha \text { (Hypoxia- } \\
\text { inducible factor- } 1 \alpha \text { ) that suppresses } \\
\text { the metastasis of Gall Bladder } \\
\text { cancer. }\end{array}$ & [16] \\
\hline XIST & $\begin{array}{l}\text { Bladder } \\
\text { cancer }\end{array}$ & $\begin{array}{l}\text { Proliferation, invasion, and } \\
\text { migration }\end{array}$ & $\begin{array}{l}\text { XIST targets androgen receptor } \\
\text { binding with miR-124 and } \\
\text { facilitates proliferation, invasion, } \\
\text { and Migration. }\end{array}$ & [24] \\
\hline MALAT1 & $\begin{array}{l}\text { Hepatocellular } \\
\text { carcinoma }\end{array}$ & Migration and invasion & $\begin{array}{l}\text { miR-204 targets SIRT1 to suppress } \\
\text { the growth and invasion of } \\
\text { hepatocellular carcinoma. } \\
\text { MALAT1 attaches competitively to } \\
\text { miR-204- SIRT1 and promotes } \\
\text { migration and invasion. }\end{array}$ & {$[20]$} \\
\hline TUG1 & Gastric cancer & Proliferation & $\begin{array}{l}\text { TUG1 arrests G0/G1 cell cycle and } \\
\text { plays a vital role in the regulation of } \\
\text { proliferation of cell by silencing } \\
\text { p57 epigenetically. }\end{array}$ & [25] \\
\hline SNHG20 & $\begin{array}{l}\text { Non-small cell } \\
\text { lung cancer }\end{array}$ & $\begin{array}{l}\text { Cell proliferation, migration and } \\
\text { induced cell apoptosis. }\end{array}$ & $\begin{array}{l}\text { SNHG20 suppresses P21 expression } \\
\text { by interacting with the enhancer of } \\
\text { zeste homolog } 2(\mathrm{EZH} 2)\end{array}$ & [26] \\
\hline HOXA11as & $\begin{array}{c}\text { Serous } \\
\text { ovarian cancer }\end{array}$ & $\begin{array}{l}\text { cell proliferation } \\
\text { and invasion }\end{array}$ & $\begin{array}{l}\text { HOXA11as regulates expression of } \\
\text { genes like matrix metalloproteinase } \\
9 \text { (MMP-9, vascular endothelial } \\
\text { growth factor (VEGF), B-catenin } \\
\text { and others which are implicated in } \\
\text { the progression of serous ovarian } \\
\text { cancer. }\end{array}$ & [27] \\
\hline SPRY4-IT1 & $\begin{array}{l}\text { Colorectal } \\
\text { cancer }\end{array}$ & $\begin{array}{l}\text { Larger tumor, cell proliferation, } \\
\text { migration and invasion }\end{array}$ & $\begin{array}{l}\text { SPRY4-IT1 regulates epithelial- } \\
\text { mesenchymal transition (EMT) and } \\
\text { aids in the migration and invasion. }\end{array}$ & [28] \\
\hline BC200 & $\begin{array}{l}\text { Broad } \\
\text { spectrum of } \\
\text { cancers }\end{array}$ & Proliferation & $\begin{array}{l}\text { Elevation of expression level leads } \\
\text { to the proliferation. }\end{array}$ & [29] \\
\hline
\end{tabular}


Basing on the examples given above, it is well established that lncRNAs key players in the cancer progression, but what about the proteins encoded by them? Do they have any potential to get translated into proteins? Are they having any potential role in cancer? This topic has become a much of a debate now.

Based on some studies, lncRNAs own the potential to get translated into too short peptides, this feature is observed in the ribosome protection patterns [30], [31], [32]. The regions of translated transcripts can be examined using ribosome profiling involves the sequencing of ribosome protected fragments [30].

Wilson and Masel. [33] Found in Yeast that novel protein-coding genes arise from noncoding sequences. According to Xie et al.. long non-coding RNAs with active and regulated transcriptional properties could be the origin of the newly evolved proteins [34] As reported by Ruiz-Orera et al., there are strong similarities between lncRNA molecules and recently evolved protein-coding genes [35].

Assessing the properties of the sORFs in lncRNAs and young protein-coding transcripts RuizOrera et al. found that new peptides could be encoded by lncRNAs [35]. There emerges another proof from Mackowiak et al. that sORFs get translated and exhibits some wide conservation between vertebrates and invertebrates [36].

Recently, IncRNA LINC00961 encoded a polypeptide called SPAR (Small Regulatory Polypeptide of Amino acid Response) which aids in the muscle regeneration [37]. The data provided by Matsumoto, A et al.. the short proteins encoded by IncRNA can orchestrate the biological processes in line with the requirements of specific tissues [37]. Another example Myoregulin (MLN) a micro peptide encoded by a putative long non-coding RNA known to regulate skeletal muscle physiology [38]. 
Aggregated data shed light on the possibility of coding potential of long non-coding RNAs according to necessities in the cell.

In case of cancer, proteins translated from lncRNAs still to be found and consequently their role in the cancers. As stated by Ruiz-Orera et al.. short peptides obtained from lncRNAs undergoes degradation as soon as they get translated [35]. This must be the reason making it so challenging to uncover them. If this is the fact that they are synthesized in cancers there could be a potential chance of targeting cancer.

\section{Concluding Remarks}

Long non-coding RNA research is a quite challenging area to study. Applying them to the significantly larger segments of the diseases and studying the role of lncRNA within the cells is in fact intriguing.

At present, lncRNAs are in the discovery stage and their interventions in diseases. The Long noncoding RNAs are required to be evaluated individually to acquire knowledge of the precise function. One strategy could be using drugs in combination in which one would suppress the expression of lncRNA and another drug effectively targets tumour cell [39]. Since lncRNA works effectively utilizing diverse structures, molecules that could bind to them or alters the structure for neutralization could be developed [39].

The investigation of long non-coding RNAs should head towards finding their role in escalation suppression of a disease. The emergence of advanced technologies in RNA Biology made a significant pathway to find biomarkers. 


\section{REFERENCES}

[1] Carninci P, Kasukawa T, Katayama S, Gough J, Frith MC, Maeda N, Oyama R, Ravasi

T, Lenhard B, Wells C, et al., The transcriptional landscape of the mammalian genome. Science. 2005; 309:1559-1563.

[2] Hauptman N, Glavač D., Long Non-Coding RNAs in Cancer: Diagnostic and Prognostic Value. Med chem (Los Angeles). 2016; 6:422-424. doi:10.4172/2161-0444.1000379.

[3] J. S. Mattick., "Non-coding RNAs: the architects of eukaryotic complexity",, EMBO Reports. 2001; 2(11): 986-991.

[4] C. Lee and N. Kikyo., "Strategies to identify long noncoding RNAs involved in gene regulation". Cell \& Bioscience. 2012; 2(1): 37.

[5] J. J. Quinn and H. Y. Chang., "Unique features of long noncoding RNA biogenesis and function," Nature Reviews. Genetics.2016; 17( 1): 47-62.

[6] Mansi A. Parasramka, Sayantan Maji, Akiko Matsuda, Irene K. Yan, Tushar Patel., Long non-coding RNAs as novel targets for therapy in hepatocellular carcinoma. Pharmacology \& Therapeutics.2016; 161:67-78. http://dx.doi.org/10.1016/j.pharmthera.2016.03.004

[7] Gong Z, Zhang S, Zhang W, Huang H, Li Q, Deng H, Ma J, Zhou M, Xiang J, Wu M, Li X. Long non-coding RNAs in cancer. Science China Life Sciences. 2012; 1:55(12):1120-4.

[8] Yap K L, Li S, Munoz-Cabello A M, et al. Molecular interplay of the noncoding RNA ANRIL and methylated histone H3 lysine 27 by polycomb CBX7 in transcriptional silencing of INK4a. Mol Cell. 2010; 38: 662-674

[9] Rinn J L, Kertesz M, Wang J K, et al. Functional demarcation of active and silent chromatin domains in human HOX loci by noncoding RNAs. Cell. 2007;129: 1311-1323 
[10] Liang X, Ma J, Schatten H, et al. Epigenetic changes associated with oocyte aging. Sci China Life Sci. 2012;55: 670-676

[11] Huang H, Jiao R. Roles of chromatin assembly factor 1 in the epigenetic control of chromatin plasticity. Sci China Life Sci, 2012; 55: 15-19

[12] Chao S, Li J, Jin X, et al. Epigenetic reprogramming of embryos derived from sperm frozen at -20 degrees C. Sci China Life Sci. 2012; 55: 349-357

[13] Bi X. Functions of chromatin remodeling factors in heterochromatin formation and maintenance. Sci China Life Sci. 2012; 55: 89-96

[14] Ling H Y, Hu B, Feng S D, et al. The role of epigenetic regulation in diabetes and its complications. Prog Biochem Biophys. 2012; 39: 14-21

[15] Gupta RA, Shah N, Wang KC, et al. Long non-coding RNA HOTAIR reprograms chromatin state to promote cancer metastasis. Nature. 2010; 464(7291):1071-6.

[16] Cai Q, Wang Z, Wang S, Weng M, Zhou D, Li C, Wang J, Chen E, Quan Z. 2017 Long non-coding RNA LINC00152 promotes gallbladder cancer metastasis and epithelialmesenchymal transition by regulating HIF-1a via miR-138. Open Biol. 7: 160247.http://dx.doi.org/10.1098/rsob.160247

[17] Li, W., Sun, M., Zang, C., Ma, P., He, J., Zhang, M., ... \& Shu, Y. Upregulated long non-coding RNA AGAP2-AS1 represses LATS2 and KLF2 expression through interacting with EZH2 and LSD1 in non-small-cell lung cancer cells. Cell death \& disease. 2017;7(5):e2225.doi:10.1038/cddis.2016.126

[18] Francesco P. Marchese, Ivan Raimondi, and Maite Huarte., The multidimensional mechanisms of long noncoding RNA function. Genome Biology. 2017; 18: 206. DOI $10.1186 / \mathrm{s} 13059-017-1348-2$ 
[19] Chung-Chau Hon, Jordan A. Ramilowski, Jayson Harshbarger, Nicolas Bertin ., An atlas of human long non-coding RNAs with accurate 5' ends. Nature. 2017; 543: 199-204. doi:10.1038/nature21374.

[20] Hou, Z., Xu, X., Zhou, L., Fu, X., Tao, S., Zhou, J., ... \& Liu, S. (2017). The long noncoding RNA MALAT1 promotes the migration and invasion of hepatocellular carcinoma by sponging miR-204 and releasing SIRT1. Tumor Biology. 39(7): 1010428317718135.

[21] Arunoday Bhan, Milad Soleimani and Subhrangsu S. Mandal., Long Noncoding RNA and Cancer: A New Paradigm. Cancer Res. 2017;77(15): 1-17. DOI: 10.1158/00085472.CAN-16-2634

[22] Gibb EA, Brown CJ, Lam WL. The functional role of long non-coding RNA in human carcinomas. Molecular cancer. 201;10(1):38.

[23] Oskar Marín-Béjar , Mas AM, González J, Martinez D, Athie A, Morales X, ., The human lncRNA LINC-PINT inhibits tumor cell invasion through a highly conserved sequence element. Genome Biol. 2017; 18: 202. https://doi.org/10.1186/s13059-017-1331-y

[24] Xiong, Y., Wang, L., Li, Y., Chen, M., He, W., \& Qi, L. The long non-coding RNA XIST interacted with MiR-124 to modulate bladder cancer growth, invasion, and migration by targeting androgen receptor (AR). Cellular Physiology and Biochemistry. 2017; 43(1): 405-418.DOI: 10.1159/000480419

[25] Zhang, E., He, X., Yin, D., Han, L., Qiu, M., Xu, T., ... \& De, W. Increased expression of long noncoding RNA TUG1 predicts a poor prognosis of gastric cancer and regulates cell proliferation by epigenetically silencing of p57. Cell death \& disease. 2017; 7(2):e2109.doi:10.1038/cddis.2015.356 
[26] Chen, Z., Chen, X., Chen, P., Yu, S., Nie, F., Lu, B., ... \& Wang, W. Long non-coding RNA SNHG20 promotes non-small cell lung cancer cell proliferation and migration by epigenetically silencing of P21 expression. Cell death \& disease. 2017; 8(10):e3092.doi:10.1038/cddis.2017.484

[27] Yim, G. W., Kim, H. J., Kim, L. K., Kim, S. W., Kim, S., Nam, E. J., \& Kim, Y. T. Long non-coding RNA HOXA11 antisense promotes cell proliferation and invasion and predicts patient prognosis in serous ovarian cancer. Cancer research and treatment: official journal of Korean Cancer Association. 2017; 49(3): 656.https://doi.org/10.4143/crt.2016.263

[28] Shen, F., Cai, W. S., Feng, Z., Chen, J. W., Feng, J. H., Liu, Q. C., ... \& Xu, B. (). Long non-coding RNA SPRY4-IT1 pormotes colorectal cancer metastasis by regulate epithelialmesenchymal transition. Oncotarget. 2017;8(9):14479.

[29] Booy, E. P., McRae, E. K., Koul, A., Lin, F., \& McKenna, S. A. The long non-coding RNA BC200 (BCYRN1) is critical for cancer cell survival and proliferation. Molecular cancer. 2017;16(1):109.DOI 10.1186/s12943-017-0679-7

[30] Ingolia NT. Ribosome profiling: new views of translation, from single codons to genome scale. Nature Reviews Genetics 2014;15:205-213. doi: 10.1038/nrg3645.

[31] Bazzini AA, Johnstone TG, Christiano R, Mackowiak SD, Obermayer B, Fleming ES, Vejnar CE, Lee MT, Rajewsky N, Walther TC, Giraldez AJ. Identification of small ORFs in vertebrates using ribosome footprinting and evolutionary conservation. The EMBO Journal 2014;33:981-993. doi: 10.1002/embj.201488411.

[32]Juntawong P, Girke T, Bazin J, Bailey-Serres J. Translational dynamics revealed by genome-wide profiling of ribosome footprints in Arabidopsis. Proceedings of the National Academy of Sciences of USA 2014;111: E203-E212. doi: 10.1073/pnas.1317811111. 
[33] Wilson BA, Masel J. Putatively noncoding transcripts show extensive association with ribosomes. Genome Biology and Evolution 2011;3:1245-1252. doi: 10.1093/gbe/evr099.

[34] Xie C, Zhang YE, Chen JY, Liu CJ, Zhou WZ, Li Y, Zhang M, Zhang R, Wei L, Li CY. Hominoid-specific de novo protein-coding genes originating from long non-coding RNAs. PLOS Genetics 2012;8:e1002942. doi: 10.1371/ journal.pgen.1002942.

[35] Ruiz-Orera, Jorge, Xavier Messeguer, Juan Antonio Subirana, and M. Mar Alba. "Long non-coding RNAs as a source of new peptides." Elife 2014;3: e03523.

[36] Mackowiak, Sebastian D., Henrik Zauber, Chris Bielow, Denise Thiel, Kamila Kutz, Lorenzo Calviello, Guido Mastrobuoni et al. "Extensive identification and analysis of conserved small ORFs in animals." Genome biology 2015;16 (1): 179.

[37] Matsumoto, A.; Pasut, A.; Matsumoto, M.; Yamashita, R.; Fung, J.; Monteleone, E.; Saghatelian, A.;Nakayama, K.I.; Clohessy, J.G.; Pandolfi, P.P. mTORC1 and muscle regeneration are regulated by the LINC00961-encoded SPAR polypeptide. Nature 2017; 541:228-232.

[38] Anderson DM, Anderson KM, Chang CL, Makarewich CA, Nelson BR, McAnally JR, Kasaragod P, Shelton JM, Liou J, Bassel-Duby R, Olson EN. A micropeptide encoded by a putative long noncoding RNA regulates muscle performance. Cell. 2015;12:160(4):595-606.

[39] Nina Hauptman and Damjan Glavač. Long Non-Coding RNA in Cancer. Int. J. Mol. Sci. 2013; 14: 4655-4669; doi:10.3390/ijms14034655 